\title{
Antigen presenting epithelial cells play a pivotal role in airway allergy
}

\author{
Julia Arebro ${ }^{1 *}$, Lotta Tengroth ${ }^{1}$, Susanna Kumlien Georén ${ }^{1}$, Ola Winqvist ${ }^{2}$, Lars-Olaf Cardell ${ }^{1}$ \\ From The 10th Symposium of Experimental Rhinology and Immunology of the Nose (SERIN 2015) \\ Stockholm, Sweden. 19-21 February 2015
}

\section{Background}

Epithelial cells are known to express MHC class II, but their ability to process and present allergens thus contributing to the development of upper airway disease is unclear. The aim of this study was to establish antigen presenting nasal epithelial cells as a significant factor in the allergic reaction.

\section{Method}

Mucosal specimen from human and mice were used to evaluate the ability of nasal epithelial cells to take up antigen, express MHC class II and co-stimulatory molecules and to stimulate antigen-specific activation and proliferation of $\mathrm{CD} 4+\mathrm{T}$ cells.

\section{Results}

Human nasal epithelial cells were shown to take up dextran, which ended up in intracellular endosome-like structures. In addition, MHC class II and co-stimulatory molecules were found on human and mouse nasal epithelial cells. Functionally, nasal epithelial cells from ovalbumin-sensitized mice activated and induced antigen-specific proliferation of naïve OT-II CD4+ T cells in vitro. A similar activation was not seen in naïve MNECs. Finally, nasal epithelial cells from allergic rhinitis patients were able to activate autologous $\mathrm{T}$ cells against Bet $\mathrm{v} 1$ and induce IL-13 release.

\section{Conclusion}

The present data reveal a significant role for airway epithelial cells in antigen presentation by demonstrating their ability to take up, process and present antigens in a class II dependent manner for the activation of allergen-specific CD4+ T cells. Therefore, the present study establish for the first time nasal epithelial cells as important antigen

${ }^{1}$ Karolinska Institutet, ENT-department, Stockholm, Sweden

Full list of author information is available at the end of the article presenting cells in airway allergy by initiating a local adaptive immune response.

\section{Authors' details}

${ }^{1}$ Karolinska Institutet, ENT-department, Stockholm, Sweden. ${ }^{2}$ Karolinska Institutet, Dep. of Medicine, Unit of Translational Immunology, Stockholm, Sweden.

\section{Published: 26 June 2015}

\section{doi:10.1186/2045-7022-5-S4-O8}

Cite this article as: Arebro et al:: Antigen presenting epithelial cells play a pivotal role in airway allergy. Clinical and Translational Allergy 20155 (Suppl 4):O8.
Submit your next manuscript to BioMed Central and take full advantage of:

- Convenient online submission

- Thorough peer review

- No space constraints or color figure charges

- Immediate publication on acceptance

- Inclusion in PubMed, CAS, Scopus and Google Scholar

- Research which is freely available for redistribution
() Biomed Central

\section{Biomed Central}

